\title{
Effect of Supplementation of Ajwain (Trachyspermum ammi L.) on the Growth of Pratapdhan Chicken
}

\author{
Anurag $^{1}$, Sarita Kumari ${ }^{2 *}$ and Attar Uddin $^{3}$ \\ ${ }^{1}$ Department of Livestock Production and Management, Mahatma Jyotiba Fule College of \\ Veterinary and Animal Science, Chomu, Jaipur (Rajasthan University of Veterinary and \\ Animal Sciences, Bikaner), Jaipur, India \\ ${ }^{2}$ Department of Livestock Products Technology, Post Graduate Institute of Veterinary \\ Education and Research (Rajasthan University of Veterinary and Animal Sciences, Bikaner), \\ Jaipur, India \\ ${ }^{3}$ Department of Livestock Production and Management, Sri Karan Narendra Agriculture \\ University, Jobner, Jaipur, India \\ *Corresponding author
}

\section{A B S T R A C T}

\begin{tabular}{|l|}
\hline K e y w o r d s \\
Pratapdhan chicken, \\
Ajwain, Standard Chick \\
Ration, Growth \\
Performance, \\
Supplementation
\end{tabular}

The objective of this study was to evaluate the effect of dietary supplementation of Ajwain (Trachyspermum ammi L.) on the growth of Pratapdhan chicken. An experiment was conducted on 120 unsexed Pratapdhan chicks (day old) randomly design in 4 treatment groups with 3 replicates, each consisting of 10 chicks. Three treatment groups were as follows - T1: Standard chick ration as per BIS standards; T2: Standard chick ration supplemented with $0.1 \%$ Ajwain; T3: Standard chick ration supplemented with $0.2 \%$ Ajwain; and T4: Standard chick ration supplemented with $0.3 \%$ Ajwain. The results obtained regarding performance of the Pratapdhan chicken showed that, the significant difference was observed in body weight and body weight gain than the control group. The body weight $(\mathrm{g})$ of the chicks at 8 weeks of age was the highest in $\mathrm{T}_{3}$ chicks $(1203 \pm 42.24)$, followed by $\mathrm{T}_{2}(1158.39 \pm 45.10), \mathrm{T}_{4}$ $(1140.46 \pm 36.35)$ and $\mathrm{T}_{1}(1130.88 \pm)$, respectively. The weekly body weight gain $(215.26 \pm 2.88)$ was highest in $\mathrm{T}_{3}$ the difference was significant over control group. The total feed intake $(\mathrm{g})$ was lowest in $\mathrm{T}_{3}$ (3017) followed $\mathrm{T}_{2}(3073), \mathrm{T}_{1}(3206)$ and $\mathrm{T}_{4}$ (3234). The increase in the feed intake of $\mathrm{T}_{4}$ group may be due to the laxative and purgative effect of Ajwain. The feed conversion ratio (3.28 \pm 0.02 ) of $\mathrm{T}_{3}$ group was also found better over the control group. Performance index of $T_{3}(65.54 \pm 1.76)$ group was significantly higher than the other groups. Similar trend was also found in Protein efficiency $(1.51 \pm 0.02)$ and energy efficiency $(10.87 \pm 0.28)$. On the basis of the result of the present study, it is concluded that dietary addition of Ajwain has a positive effect on performance of Pratapdhan chicks when added at the $0.2 \%$ of broiler ration and can be alternative a growth promoter in feeding of broiler ration. 


\section{Introduction}

Poultry farming has become a remunerative business and pre-eminence over all other livestock enterprises in the developing countries. It carries a scope for quick and large economic profit compared to other livestock resources in the rural and urban mass. In recent years, backyard poultry production has been extremely emphasized in sustaining and enhancing rural livelihoods. Looking into the importance of backyard rural poultry farming in India, several research organizations have developed different backyard chicken varieties which have successfully been reared by farmers from many parts of the country. These improved varieties include Gramapriya, CARI-Nirbhic, CARI-Shyama, Vanaraja, Pratapdhan, Gramalaxmi and Nicobari etc. The broiler meat is economic, cheaper, free from social taboo and good source of animal protein. The poultry meat production is estimated to be 3.26 million tonnes and contribute around $46 \%$ of total meat production in 2016-17 (DAHDF, 2017). According to nutritional advisory Committee recommended level of per capita poultry meat is $10.8 \mathrm{~kg}$ annually, however, to date, it's not fulfilled by poultry sector. Several growth promoting feed additives are commonly added in broiler diets for increasing the growth performance, viability of chick and control the disease. The main feed additives used in broiler diet are antibiotics, coccidiostat, antistress, probiotics, prebiotics, symbiotics, enzymes, organic acids, toxin binders, hormones, arsenicals etc. The European Union has banned feed grade antibiotic growth promoters, because of the risk of possible drug resistance in human pathogenic bacteria and other side effects (Cogliani, 2011). Feeds containing no chemical additives are increasingly used in poultry nutrition. Herbal feed additives are being investigated as natural sources of biologically important substances. In an age of increasing drugs resistance, their side effects and high cost of medication, there is worldwide acceptance of the use of herbal feed additives.

Herbs and herbal products have a positive effect on broiler growth performance (Guo et al., 2000). The number of herbal growth promoter feed supplements like, Liv-52, livol, Nitrovin, Virginiamycin, Flavomycin, Shatavari, Gudchi, turmeric, garlic and Ashwagandha etc, have been tried by earlier workers to stimulate the growth and egg production in fowl. Jamroz and Kamel (2002) have demonstrated that replacing the antibiotic growth promoter avilamycine by XT (a blend of capsicum, cinnamaldehyde and carvacrol) as a herb significantly improved liveweight, better weight gains and feed efficiency of broiler during the experimental period.

Ajwain (Trachyspermum ammi L.) is an annual herb belong to family Apiaceae and originated in eastern regions of Persia and India. The Rajasthan, Gujarat and Madhya Pradesh are main Ajwain growing states in India. Morsi, 2002 reported that Ajwain contains principle active compounds includes phenols, mainly thymol and carvacrol have antiseptic, antifungal, antibacterial and anthelminthic effects. Ajwain is highly esteemed as a remedial agent for flatulence, flatulent colic, atonic dyspepsia, diarrhoea- in short, as a digestive aid and also as an antiseptic (Bentely and Wrimen, 1999). Some researcher proved that an increase in body weight and decrease in feed efficiency when Ajwain and other herbal ingredients used as dietry supplement in broilers diets (Valiollahi et al., 2014, Great head, 2003). So, Ajwain as growth promoters is a good alternative to antibiotic and commercial growth promoter because of easy availability and cost effectiveness. The study entails the effect of dietary supplementation of Ajwain at different concentration on live weight, body weight, feed consumption, feed conversation ratio, 
performance index, protein efficiency ratio and energy efficiency ratio in Pratapdhan breed of chicken.

\section{Materials and Methods}

The experiment was conducted at Poultry farm, S.K.N. College of Agriculture, Jobner District Jaipur, (Rajasthan, India). Geographically Jobner is located $45.0 \mathrm{~km}$ west of Jaipur at $26^{0} 05^{\prime}$ North latitude, $75^{0} 28^{\prime}$ East longitude and at an altitude of 427 meter above the mean sea level. The area falls in agro-climatic zone III-A (Semi-arid eastern plain zone of Rajasthan). The 120 chicks (day old) of Pratapdhan breed of chicken were procured from the project "Aangan me Murgi palan", funded by R.K.V.Y. (Rashtriya Krishi Vikas Yojana) running in the department of Livestock Production Management at Sri Karan Narendra College of Agriculture, Jobner. The chicks were randomly distributed over four treatment groups each having 30 chicks. Each of the treatment was replicated three times, with ten birds per replicate in a Completely Randomized Design (CRD). Good quality Ajwain seed was purchased from the local market in one slot. The seed were grind to fine powder and mixed properly at appropriate concentrations in the feed as specified for different treatments. $T_{1}$ group was provided standard chick ration as per BIS (2007) specifications without any supplementation and served as control, $\mathrm{T}_{2}$ received standard chick ration with Ajwain powder supplementation in feed @ $0.1 \%, \mathrm{~T}_{3}$ standard chick ration with Ajwain powder supplementation in feed @ $0.2 \%$ and $\mathrm{T}_{4}$ standard chick ration with Ajwain powder supplementation in feed @ $0.3 \%$. The experimental birds were nearly equal in the live body weight at the start of the experiment. The experiment was extended up to 8 weeks of age. Feed and water were supplied adlibitum during the experimental periods. Chicks were grown in brooders with raised wire floors and exposed to 24 hours of constant light (12 hrs on day light and the rest on artificial lighting, using 40 watt bulbs). All chicks were kept under the same environmental and hygienic conditions. Live weight, body weight gain, feed consumption, feed conversion ratio, performance index, protein efficiency ratio and energy efficiency ratio were recorded during the experiment period.

\section{Statistical analysis}

Data obtained were subjected to statistical analysis as per Snedecor and Cochran (1994) using Completely Randomized Design (CRD). All the data were subjected to ANOVA using the General Linear Models procedure of SAS software (SAS Institute, 2003). The mean differences among different treatments were separated by Duncan's multiple range tests. Consequently, a level of (P\&lt; 0.05) was used as the criterion for statistical significance (Duncan, 1955).

\section{Results and Discussion}

\section{Body weight}

The data of mean body weight of Pratapdhan chicken fed on Ajwain supplemented diet with $0,0.1,0.2$ and $0.3 \%$ Ajwain recorded at 0, 7, $14,21,28,35,42,49$ and 56 days of age are presented in Table 1. The corresponding final body weights of Pratapdhan chicken recorded on 56 days of age were 1130.88, 1158.39, 1203.50 and $1140.46 \mathrm{~g}$ in $\mathrm{T}_{1}, \mathrm{~T}_{2}, \mathrm{~T}_{3}$ and $\mathrm{T}_{4}$, respectively. The overall weight gain in $\mathrm{T}_{3}$ (0.2\% Ajwain) was significantly higher than all other treatment groups. The present study results are in agreement with results of Valliolahi et al., (2014) who observed that body weight was significantly higher in birds fed diet containing Ajwain 0.02\% than birds fed the control diet. Similar results were also observed by Tripathi et al., (2013) on feeding 
of $0.5 \%$ Ajwain and concluded that Ajwain significantly improve the performance of Japanese quail broiler. Findings are close with Srivastava et al., (2012), Nath et al., (2012) and Omar et al., (2016) they observed that body weight was significantly higher in birds fed diet containing growth promoters than birds fed control diet.

\section{Weekly body weight gain}

The mean weight gain (g)/bird/week of Pratapdhan chicken reared under different treatments is presented in Table 2. The average body weight gain (g)/bird/week of Pratapdhan chicken showed statistically significant $\quad(\mathrm{P}<0.05)$ differences among various treatments at all ages. At the age of one week the weight gain in $\mathrm{T}_{3}$ group was found significantly higher than other treatments. However at the end of second week it was higher than control. During the third week only the chicks of $\mathrm{T}_{4}$ treatment group gained significantly higher body weight perhaps due to their stunted growth in first and second week. Dinodiya et al., (2015) also reported the similar results. While in $4^{\text {th }}, 5^{\text {th }}$, $6^{\text {th }}, 7^{\text {th }}$ and $8^{\text {th }}$ week $T_{3}$ gain significantly higher body weight than all other treatments. The weekly body weight gain was highest at $7^{\text {th }}$ week range from $200.18\left(\mathrm{~T}_{1}\right)$ to $231.36\left(\mathrm{~T}_{3}\right)$ grams. These results are in conformity with the findings of Tripathi et al., (2013) who found that the supplementation feeding of Ajwain $(0.5 \%)$, hot red pepper $(0.5 \%)$ and black pepper $(0.25 \%)$ significantly $(\mathrm{P}<0.05)$ improved of body weight gain in Japanese quail broiler. Dinodiya et al., (2015) also reported the significant effect on body weight gain with supplementation of marketed herbal (Herbstone) nutraceuticals fed @ 2\% of concentrate ration and herbal feed additive Herbiotic-FS @ 250 and 500g/ton of feed than control group in broilers. But the contrary results was observed by Demir et al., (2003) and reported a non significantly $(\mathrm{P}<0.05)$ body weight gain in broiler chicken fed with oregano, du-sacch, quiponin, garlic and thyme over those of control group.

\section{Feed consumption}

The mean feed consumption per bird at weekly interval under different treatments is presented in Table 3. The mean feed consumption of Pratapdhan chicken during 8 weeks of experiment remained significantly lower $(\mathrm{P}<0.05)$ in the treatment group $\mathrm{T}_{3}$ as compared to the control. However in the $7^{\text {th }}$ and $8^{\text {th }}$ weeks of age the weekly feed consumption was found highest in $\mathrm{T}_{4}(0.3 \%$ Ajwain) as compare to all treatment groups. It may be due to the slightly laxative effect of Ajwain as reported by Apte et al., (2014). The mean weekly feed intake values recorded during $8^{\text {th }}$ week of experiment ranged from $763\left(\mathrm{~T}_{4}\right)$ to $707\left(\mathrm{~T}_{3}\right)$ grams. Similar conclusion was drawn by Srivastava et al., (2012), they concluded that broilers fed with indigenous herbal drug (Withania somnifera, Asparagus racemosus, Mucuna pruriens) showed the significant $(\mathrm{P}<0.05)$ effect on decreased feed intake. Demir et al., (2003) also observed significantly $(\mathrm{P}<0.05)$ less feed intake in broiler fed on herbal and antibiotic growth promoters than control. On the contrary, Chen et al., (2003) reported an increase in feed intake at the supplementation of $3 \%$ chicory root powder. Valliolahi et al., (2014) also found that the feed intake (FI) was increased in treated groups than control using Sumac and Ajwain powder.

\section{Feed conversion ratio}

The mean weekly feed conversion ratio (FCR) of Pratapdhan chicks provided chick feed with supplementation of Ajwain is presented in Table 4. The weekly mean FCR values of $\mathrm{T}_{3}$ were significantly lower $(\mathrm{P}<0.05)$ as compared to control group $\left(\mathrm{T}_{1}\right)$ and all other treatments during all weeks of age. 
Int.J.Curr.Microbiol.App.Sci (2018) 7(5): 3163-3172

Table.1 Treatment means of average body weight ( $\mathrm{g} / \mathrm{bird}$ ) during different growth periods

\begin{tabular}{|l|l|l|l|l|}
$\begin{array}{l}\text { Age } \\
\text { (days) }\end{array}$ & $\mathrm{T}_{1}$ & $\mathrm{~T}_{2}$ & $\mathrm{~T}_{3}$ & $\mathrm{~T}_{4}$ \\
\hline 0 & $44.20 \pm 00.91$ & $44.00 \pm 01.01$ & $44.40 \pm 00.89$ & $44.13 \pm 00.86$ \\
\hline 7 & $77.26^{\mathrm{b}} \pm 01.05$ & $82.53^{\mathrm{b}} \pm 00.91$ & $84.56^{\mathrm{a}} \pm 00.86$ & $72.76^{\mathrm{c}} \pm 01.11$ \\
\hline 14 & $131.83^{\mathrm{b}} \pm 01.35$ & $144.21^{\mathrm{a}} \pm 01.11$ & $145.46^{\mathrm{a}} \pm 01.25$ & $130.66^{\mathrm{b}} \pm 01.12$ \\
\hline 21 & $215.62^{\mathrm{b}} \pm 05.22$ & $225.71^{\mathrm{a}} \pm 06.88$ & $226.73^{\mathrm{a}} \pm 09.18$ & $223.11^{\mathrm{a}} \pm 05.65$ \\
\hline 28 & $350.75^{\mathrm{b}} \pm 04.47$ & $354.05^{\mathrm{a}} \pm 05.52$ & $355.26^{\mathrm{a}} \pm 05.49$ & $349.76^{\mathrm{b}} \pm 03.09$ \\
\hline 35 & $535.63^{\mathrm{bc}} \pm 10.22$ & $553.11^{\mathrm{a}} \pm 12.31$ & $546.63^{\mathrm{ab}} \pm 15.74$ & $529.83^{\mathrm{c}} \pm 13.40$ \\
\hline 42 & $734.56^{\mathrm{b}} \pm 16.02$ & $753.23^{\mathrm{a}} \pm 16.06$ & $756.86^{\mathrm{a}} \pm 13.46$ & $726.76^{\mathrm{c}} \pm 08.80$ \\
\hline 49 & $934.74^{\mathrm{c}} \pm 28.31$ & $959.37^{\mathrm{b}} \pm 29.61$ & $988.23^{\mathrm{a}} \pm 40.47$ & $937.80^{\mathrm{c}} \pm 28.12$ \\
\hline 56 & $1130.88^{\mathrm{d}} \pm 35.19$ & $1158.39^{\mathrm{b}} \pm 45.10$ & $1203.50^{\mathrm{a}} \pm 42.24$ & $1140.46^{\mathrm{c}} \pm 36.35$ \\
\hline
\end{tabular}

(a) Each value is a mean of three replicates.

(b) Means bearing different superscripts, differ significantly $(\mathrm{P}<0.05)$ row wise.

Table.2 Effect of Ajwain on mean weekly weight gain (g)/bird of Pratapdhan chicken

\begin{tabular}{l|l|l|l|l|}
\multirow{2}{*}{ Week } & \multicolumn{4}{|c}{ Treatments } \\
\cline { 2 - 5 } & $\mathrm{T}_{1}$ & $\mathrm{~T}_{2}$ & $\mathrm{~T}_{3}$ & $\mathrm{~T}_{4}$ \\
\hline 1 & $33.06^{\mathrm{c}} \pm 0.58$ & $37.01^{\mathrm{b}} \pm 1.14$ & $40.16^{\mathrm{a}} \pm 0.76$ & $28.63^{\mathrm{d}} \pm 0.42$ \\
\hline 2 & $54.56^{\mathrm{b}} \pm 2.23$ & $61.68^{\mathrm{a}} \pm 1.33$ & $60.90^{\mathrm{a}} \pm 1.49$ & $57.90^{\mathrm{ab}} \pm 0.06$ \\
\hline 3 & $79.25^{\mathrm{b}} \pm 4.33$ & $81.49^{\mathrm{b}} \pm 2.31$ & $81.26^{\mathrm{b}} \pm 2.45$ & $92.43^{\mathrm{a}} \pm 1.80$ \\
\hline 4 & $127.42^{\mathrm{ab}} \pm 0.34$ & $128.34^{\mathrm{a}} \pm 0.06$ & $128.53^{\mathrm{a}} \pm 0.27$ & $126.66^{\mathrm{b}} \pm 0.56$ \\
\hline 5 & $184.88^{\mathrm{b}} \pm 2.90$ & $186.41^{\mathrm{b}} \pm 1.04$ & $191.36^{\mathrm{a}} \pm 1.35$ & $180.06^{\mathrm{b}} \pm 2.31$ \\
\hline 6 & $198.92^{\mathrm{b}} \pm 6.24$ & $200.11^{\mathrm{b}} \pm 4.66$ & $210.23^{\mathrm{a}} \pm 11.54$ & $196.88^{\mathrm{b}} \pm 5.77$ \\
\hline 7 & $200.18^{\mathrm{c}} \pm 3.93$ & $206.14^{\mathrm{bc}} \pm 3.48$ & $231.36^{\mathrm{a}} \pm 2.52$ & $211.10^{\mathrm{b}} \pm 2.80$ \\
\hline 8 & $196.14^{\mathrm{b}} \pm 2.66$ & $199.01^{\mathrm{b}} \pm 2.31$ & $215.26^{\mathrm{a}} \pm 2.88$ & $202.66^{\mathrm{b}} \pm 1.73$ \\
\hline
\end{tabular}

(a) Each value is a mean of three replicates.

(b) Means bearing different superscripts, differ significantly $(\mathrm{P}<0.05)$ row wise.

Table.3 Effect of Ajwain on mean weekly feed intake (g/bird) of Pratapdhan chicken

\begin{tabular}{l|l|l|l|l|}
\hline \multirow{2}{*}{ Week } & \multicolumn{4}{|c|}{ Treatments } \\
& $\mathrm{T}_{1}$ & $\mathrm{~T}_{2}$ & $\mathrm{~T}_{3}$ & $\mathrm{~T}_{4}$ \\
\hline 1 & $56^{\mathrm{b}} \pm 0.26$ & $56^{\mathrm{b}} \pm 0.45$ & $56^{\mathrm{b}} \pm 0.54$ & $49^{\mathrm{a}} \pm 0.50$ \\
\hline 2 & $112^{\mathrm{c}} \pm 1.23$ & $105^{\mathrm{b}} \pm .1 .15$ & $98^{\mathrm{a}} \pm 1.73$ & $112^{\mathrm{c}} \pm 2.30$ \\
\hline 3 & $182^{\mathrm{b}} \pm 1.64$ & $161^{\mathrm{a}} \pm 1.73$ & $154^{\mathrm{a}} \pm 2.30$ & $196^{\mathrm{c}} \pm 2.88$ \\
\hline 4 & $322^{\mathrm{b}} \pm 2.24$ & $294^{\mathrm{a}} \pm 2.30$ & $287^{\mathrm{a}} \pm 2.63$ & $315^{\mathrm{b}} \pm 3.46$ \\
\hline 5 & $504^{\mathrm{b}} \pm 5.77$ & $483^{\mathrm{a}} \pm 5.77$ & $476^{\mathrm{a}} \pm 5.78$ & $490^{\mathrm{ab}} \pm 5.78$ \\
\hline 6 & $609^{\mathrm{b}} \pm 2.88$ & $581^{\mathrm{a}} \pm 3.46$ & $574^{\mathrm{a}} \pm 2.88$ & $609^{\mathrm{b}} \pm 4.61$ \\
\hline 7 & $686^{\mathrm{b}} \pm 5.77$ & $679^{\mathrm{a}} \pm 2.30$ & $665^{\mathrm{a}} \pm 2.30$ & $700^{\mathrm{c}} \pm 4.04$ \\
\hline 8 & $735^{\mathrm{b}} \pm 3.46$ & $714^{\mathrm{a}} \pm 1.73$ & $707^{\mathrm{a}} \pm 1.86$ & $763^{\mathrm{c}} \pm 3.46$ \\
\hline
\end{tabular}

(a) Each value is a mean of three replicates.

(b) Means bearing different superscripts, differ significantly $(\mathrm{P}<0.05)$ row wise. 
Table.4 Effect of Ajwain on mean feed conversion ratio of Pratapdhan chicken

\begin{tabular}{l|l|l|l|l|}
\multirow{2}{*}{ Week } & \multicolumn{4}{|c|}{ Treatments } \\
& $\mathrm{T}_{1}$ & $\mathrm{~T}_{2}$ & $\mathrm{~T}_{3}$ & $\mathrm{~T}_{4}$ \\
\hline 1 & $1.69^{\mathrm{c}} \pm 0.017$ & $1.51^{\mathrm{b}} \pm 0.005$ & $1.39^{\mathrm{a}} \pm 0.017$ & $1.71^{\mathrm{c}} \pm 0.011$ \\
\hline 2 & $2.05^{\mathrm{d}} \pm 0.011$ & $1.70^{\mathrm{b}} \pm 0.046$ & $1.60^{\mathrm{a}} \pm 0.012$ & $1.93^{\mathrm{c}} \pm 0.017$ \\
\hline 3 & $2.29^{\mathrm{d}} \pm 0.017$ & $1.97^{\mathrm{b}} \pm 0.006$ & $1.89^{\mathrm{a}} \pm 0.026$ & $2.12^{\mathrm{c}} \pm 0.023$ \\
\hline 4 & $2.52^{\mathrm{d}} \pm 0.017$ & $2.29^{\mathrm{b}} \pm 0.017$ & $2.23^{\mathrm{a}} \pm 0.006$ & $2.48^{\mathrm{c}} \pm 0.028$ \\
\hline 5 & $2.82^{\mathrm{d}} \pm 0.014$ & $2.59^{\mathrm{b}} \pm 0.020$ & $2.48^{\mathrm{a}} \pm 0.023$ & $2.72^{\mathrm{c}} \pm 0.020$ \\
\hline 6 & $3.06^{\mathrm{c}} \pm 0.011$ & $2.90^{\mathrm{b}} \pm 0.023$ & $2.68^{\mathrm{a}} \pm 0.020$ & $3.09^{\mathrm{c}} \pm 0.014$ \\
\hline 7 & $3.42^{\mathrm{c}} \pm 0.024$ & $3.29^{\mathrm{b}} \pm 0.011$ & $2.92^{\mathrm{a}} \pm 0.008$ & $3.31^{\mathrm{b}} \pm 0.014$ \\
\hline 8 & $3.74^{\mathrm{c}} \pm 0.023$ & $3.58^{\mathrm{b}} \pm 0.029$ & $3.28^{\mathrm{a}} \pm 0.024$ & $3.76^{\mathrm{c}} \pm 0.011$ \\
\hline
\end{tabular}

(a) Each value is a mean of three replicates.

(b) Means bearing different superscripts, differ significantly $(\mathrm{P}<0.05)$ row wise.

Table.5 Effect of Ajwain on mean performance index of Pratapdhan chicken

\begin{tabular}{l|l|l|l|l|} 
Week & \multicolumn{4}{|c|}{ Treatments } \\
& $\mathrm{T}_{1}$ & $\mathrm{~T}_{2}$ & $\mathrm{~T}_{3}$ & $\mathrm{~T}_{4}$ \\
\hline 1 & $19.52^{\mathrm{bc}} \pm 1.07$ & $24.47^{\mathrm{ab}} \pm 1.70$ & $28.81^{\mathrm{a}} \pm 1.15$ & $16.73^{\mathrm{c}} \pm 1.70$ \\
\hline 2 & $26.58^{\mathrm{c}} \pm 2.31$ & $36.23^{\mathrm{ab}} \pm 2.30$ & $37.84^{\mathrm{a}} \pm 1.70$ & $29.93^{\mathrm{bc}} \pm 1.96$ \\
\hline 3 & $34.50^{\mathrm{b}} \pm 2.87$ & $41.24^{\mathrm{a}} \pm 2.93$ & $42.88^{\mathrm{a}} \pm 3.49$ & $43.59^{\mathrm{a}} \pm 2.94$ \\
\hline 4 & $50.42^{\mathrm{b}} \pm 3.46$ & $56.03^{\mathrm{a}} \pm 3.45$ & $57.56^{\mathrm{a}} \pm 4.63$ & $50.93^{\mathrm{b}} \pm 4.95$ \\
\hline 5 & $67.75^{\mathrm{b}} \pm 1.36$ & $71.94^{\mathrm{ab}} \pm 2.31$ & $76.92^{\mathrm{a}} \pm 1.13$ & $66.17^{\mathrm{b}} \pm 3.43$ \\
\hline 6 & $64.97^{\mathrm{b}} \pm 1.59$ & $68.92^{\mathrm{b}} \pm 1.74$ & $77.00^{\mathrm{a}} \pm 3.46$ & $63.63^{\mathrm{b}} \pm 2.05$ \\
\hline 7 & $58.41^{\mathrm{b}} \pm 1.17$ & $62.50^{\mathrm{b}} \pm 1.14$ & $80.49^{\mathrm{a}} \pm 2.82$ & $66.66^{\mathrm{b}} \pm 1.24$ \\
\hline 8 & $52.34^{\mathrm{b}} \pm 1.18$ & $55.47^{\mathrm{b}} \pm 0.57$ & $65.54^{\mathrm{a}} \pm 1.76$ & $53.83^{\mathrm{b}} \pm 0.60$ \\
\hline
\end{tabular}

(a) Each value is a mean of three replicates.

(b) Means bearing different superscripts, differ significantly $(\mathrm{P}<0.05)$ row wise.

Table.6 Effect of Ajwain on mean protein efficiency ratio of Pratapdhan chicken

\begin{tabular}{l|l|l|l|l|}
\multirow{2}{*}{ Week } & \multicolumn{2}{|l}{ Treatments } & & \\
& $\mathrm{T}_{1}$ & $\mathrm{~T}_{2}$ & $\mathrm{~T}_{3}$ & $\mathrm{~T}_{4}$ \\
\hline 1 & $2.95^{\mathrm{b}} \pm 0.05$ & $3.30^{\mathrm{a}} \pm 0.08$ & $3.58^{\mathrm{a}} \pm 0.11$ & $2.94^{\mathrm{b}} \pm 0.08$ \\
\hline 2 & $2.43^{\mathrm{b}} \pm 0.04$ & $2.93^{\mathrm{a}} \pm 0.05$ & $3.10^{\mathrm{a}} \pm 0.08$ & $2.58^{\mathrm{b}} \pm 0.07$ \\
\hline 3 & $2.17^{\mathrm{c}} \pm 0.04$ & $2.53^{\mathrm{a}} \pm 0.04$ & $2.63^{\mathrm{a}} \pm 0.05$ & $2.35^{\mathrm{b}} \pm 0.06$ \\
\hline 4 & $1.97^{\mathrm{b}} \pm 0.03$ & $2.18^{\mathrm{a}} \pm 0.04$ & $2.23^{\mathrm{a}} \pm 0.05$ & $2.01^{\mathrm{b}} \pm 0.05$ \\
\hline 5 & $1.83^{\mathrm{b}} \pm 0.02$ & $1.92^{\mathrm{ab}} \pm 0.03$ & $2.01^{\mathrm{a}} \pm 0.03$ & $1.83^{\mathrm{b}} \pm 0.05$ \\
\hline 6 & $1.63^{\mathrm{bc}} \pm 0.02$ & $1.72^{\mathrm{b}} \pm 0.02$ & $1.83^{\mathrm{a}} \pm 0.02$ & $1.61^{\mathrm{c}} \pm 0.34$ \\
\hline 7 & $1.45^{\mathrm{b}} \pm 0.01$ & $1.51^{\mathrm{b}} \pm 0.02$ & $1.72^{\mathrm{a}} \pm 0.02$ & $1.50^{\mathrm{b}} \pm 0.02$ \\
\hline 8 & $1.33^{\mathrm{bc}} \pm 0.01$ & $1.39^{\mathrm{b}} \pm 0.02$ & $1.51^{\mathrm{a}} \pm 0.02$ & $1.32^{\mathrm{c}} \pm 0.01$ \\
\hline
\end{tabular}

(a) Each value is a mean of three replicates.

(b) Means bearing different superscripts, differ significantly $(\mathrm{P}<0.05)$ row wise. 
Table.7 Effect of Ajwain on mean energy efficiency ratio of Pratapdhan chicken

\begin{tabular}{l|l|l|l|l|} 
Week & \multicolumn{4}{|c}{ Treatments } \\
& $\mathrm{T}_{1}$ & $\mathrm{~T}_{2}$ & $\mathrm{~T}_{3}$ & $\mathrm{~T}_{4}$ \\
\hline 1 & $21.08^{\mathrm{b}} \pm 0.56$ & $23.60^{\mathrm{ab}} \pm 1.44$ & $25.61^{\mathrm{a}} \pm 1.55$ & $20.86^{\mathrm{b}} \pm 0.16$ \\
\hline 2 & $17.43^{\mathrm{c}} \pm 0.84$ & $20.98^{\mathrm{ab}} \pm 1.21$ & $22.19^{\mathrm{a}} \pm 1.32$ & $18.46^{\mathrm{bc}} \pm 0.69$ \\
\hline 3 & $15.55^{\mathrm{b}} \pm 0.75$ & $18.84^{\mathrm{a}} \pm 0.45$ & $18.84^{\mathrm{a}} \pm 1.15$ & $16.84^{\mathrm{ab}} \pm 0.51$ \\
\hline 4 & $14.13^{\mathrm{c}} \pm 0.63$ & $15.59^{\mathrm{ab}} \pm 0.27$ & $15.99^{\mathrm{a}} \pm 0.39$ & $14.36^{\mathrm{bc}} \pm 0.33$ \\
\hline 5 & $13.16^{\mathrm{c}} \pm 0.08$ & $13.78^{\mathrm{ab}} \pm 0.16$ & $14.35^{\mathrm{a}} \pm 0.48$ & $13.12^{\mathrm{bc}} \pm 0.24$ \\
\hline 6 & $11.66^{\mathrm{b}} \pm 0.40$ & $12.30^{\mathrm{ab}} \pm 0.57$ & $13.08^{\mathrm{a}} \pm 0.69$ & $11.54^{\mathrm{b}} \pm 0.63$ \\
\hline 7 & $10.42^{\mathrm{b}} \pm 0.28$ & $10.84^{\mathrm{b}} \pm 0.40$ & $12.42^{\mathrm{a}} \pm 0.51$ & $10.77^{\mathrm{b}} \pm 0.46$ \\
\hline 8 & $09.53^{\mathrm{b}} \pm 0.17$ & $09.95^{\mathrm{b}} \pm 0.23$ & $10.87^{\mathrm{a}} \pm 0.28$ & $09.48^{\mathrm{b}} \pm 0.28$ \\
\hline
\end{tabular}

(a) Each value is a mean of three replicates.

(b) Means bearing different superscripts, differ significantly $(\mathrm{P}<0.05)$ row wise.

Table.8 Mortality of Pratapdhan chicken under different dietary treatments

\begin{tabular}{|l|l|l|l|l|l|l|l|l|l|l|l|} 
Treatment & $\begin{array}{l}\text { Chicks } \\
\text { taken }\end{array}$ & $1^{\text {st }}$ & $2^{\text {nd }}$ & $3^{\text {rd }}$ & $4^{\text {th }}$ & $5^{\text {th }}$ & $6^{\text {th }}$ & $7^{\text {th }}$ & $8^{\text {th }}$ & $\begin{array}{l}\text { Total } \\
\text { mortality }\end{array}$ & $\begin{array}{l}\text { Mortality } \\
\%\end{array}$ \\
\hline T1 & 30 & - & - & 1 & 1 & - & - & - & - & 2 & 6.6 \\
\hline T2 & 30 & - & 1 & - & - & 1 & - & - & - & 2 & 6.6 \\
\hline T3 & 30 & - & - & - & - & - & - & - & - & - & \\
\hline T4 & 30 & - & - & - & - & - & - & - & - & - & \\
\hline Total & 120 & & & & & & & & & 4 & 3.33 \\
\hline
\end{tabular}

The data of FCR for $\mathrm{T}_{1}$ were 1.69, 2.05, 2.29, $2.52,2.82,3.06,3.42$ and 3.74 however these were $1.39,1.60,1.89,2.23,2.48,2.68,2.92$ and 3.28 for $\mathrm{T}_{3}$ at $1^{\text {st }}, 2^{\text {nd }}, 3^{\text {rd }}, 4^{\text {th }}, 5^{\text {th }}, 6^{\text {th }}, 7^{\text {th }}$ and $8^{\text {th }}$ weeks of age, respectively.

Similarly, Aghazadeh et al., (2015) reported that the supplementation of chicory root powder (CRP) in feed showed significant decrease in the FCR of broilers compared to the control group.

This was favorably compared with earlier reports of Murthy et al., (2009), Tripathi et al., (2013) and Omar et al., (2016). On the contrary, Demir et al., (2003) and Chen et al., (2003) reported a non-significant effect on mean FCR when fed with (oregano, du sacch, quiponin, garlic, thyme and chicory root powder) herbal natural feed additives.

\section{Performance Index}

The weekly Performance Index (P.I) of birds fed diets supplemented with Ajwain is presented in Table 5. The mean P.I values of birds at 8 week remained significantly different in all the treatment groups. The mean P.I value of $T_{3}$ was significantly higher $(\mathrm{P}<0.05)$ as compared to control group $\left(\mathrm{T}_{1}\right)$ and all the treatment groups at $8^{\text {th }}$ week of age. The mean P.I value of birds recorded during $8^{\text {th }}$ week of experiment ranged from $52.34\left(\mathrm{~T}_{1}\right)$ to $65.54\left(\mathrm{~T}_{3}\right)$. Patel et al., (2014) recorded similar effects on performance index on the supplementation of garlic alone and in combination with fenugreek in the intensive production of cobb-400 broiler chicks. Meena (2015) also found an improvement in growth performance of broilers on supplementation of rosemary and fenugreek. 


\section{Protein efficiency ratio (P.E.R)}

The treatment means of protein efficiency ratio (P.E.R) showing significance of Ajwain supplementation have been shown in Table 6 . The mean P.E.R values of birds at $8^{\text {th }}$ week of age remained significantly better $(\mathrm{P}<0.05)$ in $\mathrm{T}_{3}$ as compared to all treatment groups. The data recorded were $1.33,1.39,1.51$ and 1.32 for $\mathrm{T}_{1}, \mathrm{~T}_{2}, \mathrm{~T}_{3}$, and $\mathrm{T}_{4}$, respectively at $8^{\text {th }}$ week of experiment. This was favorably compared with earlier report of Singh et al., (2015) who revealed that, all the herbal growth promoting additive treatments had better protein efficiency ratio (PER) than control. Elbushra (2012) also reported significant improvements in protein efficiency values for the groups fed diets with 0.5 and $1.5 \%$ fenugreek during the experiment period.

\section{Energy efficiency ratio (E.E.R)}

The means of energy efficiency ratio (E.E.R) showing the effect of Ajwain supplementation are given shown in Table 7. The mean values ranged between $9.48\left(\mathrm{~T}_{4}\right)$ to $10.87\left(\mathrm{~T}_{3}\right)$ at $8^{\text {th }}$ week, of age. The mean E.E.R values of birds at 8 week period remained significantly better $(\mathrm{P}<0.05)$ in $\mathrm{T}_{3}$ as compared to control. This improvement was in agreement with Safaeikatouli et al., (2012) who revealed that, all the growth promoting additive treatments had better energy efficiency ratio (EER) than control.

\section{Mortality}

The birds were observed regularly for any abnormal behavior and mortality, during the experimental period. Post-mortem findings of dead birds were recorded. The $\%$ mortality recorded has been presented in the Table 8 . The overall mortality was $3.3 \%$ during whole experimental period and it was highest $(6.6 \%)$ in control and $T_{1}$ treatment. As such on post mortem no lesion could be recorded due to effect of supplementation of Ajwain which is in agreement with those reported by Omar $e t$ al., (2016) and Eevuri and Putturu (2013).

From the results of the present investigation it can be concluded that the feeding of $0.2 \%$ Ajwain powder along with the Standard chick ration proved to be useful for better feed efficiency, improved body weight, weight gain, feed conversion ratio, performance index, protein efficiency ratio and energy efficiency ratio. It may also be concluded that in the production of chicken meat the herbal growth promoters may be used in place of chemical growth promoters to avoid the side effects of chemical growth promoters.

\section{References}

Aghazadeh, A. M. and Nabiyar, E. 2015. The effect of chicory root powder on growth performance and some blood parameters of broilers fed wheat-based diets. Journal of Applied Animal Research. 43(4): 384-389.

Apte, A. K., Khot, V. S., Biradar, N. S. and Patil, S. B. 2014. Antihelmintic activity of Trachyspermum ammi Extract. International Journal of Pharmacy and Pharmaceutical Sciences. 6(2): 236-238.

Bentely, L. S. and Wrimen, H. 1999. Medicinal Plants. Asiatic Publication House, New Delhi, India.

BIS 2007. Requirement for chicken feeds. IS: 1374-2007, Manak Bhawan, 9 Bahadurshah Zafar Marg, New Delhi 110001.

Chen, Y. C., Nakthong, C. and Chen, T. C. 2003. Improvement of Laying Hen Performance by Dietary Prebiotic Chicory Oligofructose and Inulin. International Journal of Poultry Science. 4(2): 103-108.

Cogliani, C., Goossens, H. and Greko, C. 2011. Restricting antimicrobial use in 
food animals. Lessons from European Microbiology. 6(6): 274-279.

Demir, E., Sarica, S., Özcan, M. A. and Suiçmez, M. 2003. The use of natural feed additives as alternative to an antibiotic growth promoter in broiler diets. Arch.Geflügelk. 69(3): 110-116.

Dinodiya, J., Jhirwal, A. K., Choudhary, R. S., Goswami, S. C., Choudhary, V. K., Mahla, V., Saharan, J.S. and Charan, R. 2015. Broiler performance of cobb-400 chicks with herbal versus synthetic antimicrobial feed supplements in diet. Animal Science Report. 9(1):16-21.

Duncan, D. B. 1955. Multiple range and multiple F tests. Biometrics, 11: 1-42.

Eevuri, T. R. and Putturu, R. 2013. Use of certain herbal preparation in broiler feeds. Veterinary World. 6(3): 172-179.

Elbushra, M. E. 2012. Effect of dietary Fenugreek Seeds (Trigonella foenum) as natural feed addition on broiler chicks performance. Journal of Science and Technology. 13(2): 27-33.

Great head, H. 2003. Plants and plant extracts for improving animal productivity. Proceeding of Nutrition Society. 62: 279-290.

Guo, F. C., Kwakkel, R. P., Soede, J., Williams, B. A. and Verstegen, M. W. A. 2004. Effect of a Chinese herb medicine formulation, as an alternative for antibiotics on performance of broilers. British Poultry Science. 45(6): 793-797.

Jamroz, D. and Kamel. 2002. Plant extracts enhance broiler performance. Poult. Sci.

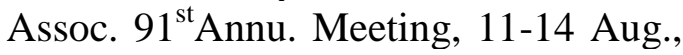
2002, Newark, Delaware. Poult. Sci. 80 (Suppl. 1), 41(Abstr.).

Meena, M. K. 2015. Effect of Feeding Rosmarinus officinalis and Trigonella foenum-graecum alone and in combination on the performance of broiler chicks. M.V.Sc. thesis. RAJUVAS, Bikaner.
Morrsi, N. M. 2000. Antimicrobial effect of crude extracts of Nigella sativa on multiple antibioticresistant bacteria. Acta Microbiologica Polonica. 49(1): 63-74.

Murthy, P. S., Borse, B. B., Khanum, H. and Srinivas, P. 2009. Inhibitory effects of Ajwain (Trachyspermum ammi) ethanolic extract on $A$. ochraceus growth \& ochratoxin production. Turky Journal of Biology. 33(2): 211-217.

Nath, D. D., Rahman, M. M., Akter, F. and Mostofa, M. 2012. Effects of tulsi, black pepper and cloves extract as a growth promoter in broiler. Bangladesh Journal of Veterinary Medicine. 10(1): $33-39$.

Omar, J. A., Hejazi, A. and Badran, R. 2016. Performance of Broilers Supplemented with Natural Herb Extract. Open Journal of Animal Sciences. 5: 68-74.

Patel, R. M., Garg, D. D, Patel, V. R., Vahora, S. G., Katariya, M. A and Choubey, M. 2014. Effect of dietary supplementation of garlic (Allium sativum) and fenugreek (Trigonella foenum-graecum) seed powder on growth performance and blood biochemical parameters in broilers. Indian Journal of Poultry Science. 49(1): 17-20.

Safaeikatouli, M., Boldaji, F., Dastar, B. and Hassani, S. 2012. The Effect of dietary silicate minerals supplementation on apparent Ileal digestibility of energy and protein in broiler chickens. International Journal of Agriculture and Biology. 14(3): 299-302.

Singh, J., Sethi, A. P. S, Sikka, S. S., Chatli, M.K. and Kumar, P. 2015. Effect of sun dried whole bulb garlic powder on growth, carcass characteristics and meat quality of commercial broilers. Indian Journal of Animal Sciences. 85(1): 6771.

Snedecor, G.W. and Cochran, W.G. (1994). Statistical method $8^{\text {th }}$ edition. Oxford 
and IBG Publication co., New Dehli, India.

Srivastava, S. B., Singh, D.P, Ram Niwas and Paswan, V. K. 2012. Effect of herbal drugs as a feed additive in broiler ration. The Bioscan. 7(2): 267-269.

Tripathi, D., Ashoka, K., Mondal, B.C., Anshu, R. and Jyoti, P. 2013. Effect of ajwain, hot red pepper and black pepper on the performance of Japanese quail.
Indian Journal of Animal Nutrition. 30: 431-433.

Valiollahi, M. R, Gholami, M., Namjoo, A. R., Rahimian, Y. and Rafiee, A. 2014. Effect of using Sumac (Rheus coriaria L.) \& Ajwain (Trachyspermum ammi) powders on performance and intestinal microbial population in broiler chicks. Research Veterinary Science. 4(10): 545-549.

\section{How to cite this article:}

Anurag, Sarita Kumari and Attar Uddin. 2018. Effect of Supplementation of Ajwain (Trachyspermum ammi L.) on the Growth of Pratapdhan Chicken. Int.J.Curr.Microbiol.App.Sci. 7(05): 3163-3172. doi: https://doi.org/10.20546/ijcmas.2018.705.370 